\title{
Case Report Form Guideline
}

National Cancer Institute

\section{Source}

National Cancer Institute. Case Report Form Guideline. NCI Thesaurus. Code C115750.

Documentation that describes how to complete a case report form. 